\title{
KONSTRUKSI KEGAGALAN IMUNISASI MR TAHAP KEDUA DALAM PEMBERITAAN MEDIA ONLINE
}

\author{
Heppy N.Y.Haloho, M.A. \\ Heppy.haloho@kalbis.ac.id
}

Kalbis Institute

\begin{abstract}
This research is intended to compare the construction of the failure of MR vaccine program in online news media (Republika online and Tempo.co) coverage. The paradigm used in this study is the constructivism paradigm with a qualitative approach. The method used in this research is the content analysis method using Robert Entman's framing device as a data analysis technique. The data in this study are news texts related to the failure of the coverage of the second phase of the MR vaccine program in Republika online and Tempo.co for the period September-November 2018. The results of this study indicate that in Tempo.co's framing, the failure of vaccine coverage was considered as a serious threat to the nation's safety due to the issuance of the illicit fatwa on MR vaccine by MUI, while in the Republika online's frame, the issue was seen as an indication of low public awareness of health and is due to various factors such as very difficult geographical conditions, the threat of health workers and the illicit fatwa on MR vaccine by MUI.
\end{abstract}

Keywords: construction of reality, online media, news framing, $m r$ vaccine coverage failure

\section{Pendahuluan}

Salah satu isu publik yang sempat menjadi pokok pemberitaan media massa di Indonesia pada akhir tahun 2018 adalah isu kegagalan Program vaksin Campak dan Rubella (MR) tahap kedua di daerah luar pulau Jawa. Sebelumnya, Program Vaksin MR tahap pertama yang diadakan di pulau Jawa pada tahun 2017 juga sempat ramai diberitakan oleh media massa (cetak, elektronik maupun media berita online) karena program tersebut menimbulkan pro dan kontra di masyarakat.

Pro dan kontra tersebut terjadi karena beredarnya isu yang menyatakan bahwa vaksin MR mengandung zat yang tidak halal dan belum mendapatkan sertifikasi halal dari Majelis Ulama Indonesia (MUI) (Juniman, 2018). Selain itu, penggunaan vaksin MR juga diduga dapat mengakibatkan gangguan kesehatan lainnya seperti kecacatan, autisme hingga kematian.

Adanya isu miring vaksin MR tersebut berdampak pada munculnya penolakan sejumlah masyarakat di berbagai daerah terhadap program vaksin MR seperti di Aceh, Riau, Sumatera Barat, Jambi dan daerahdaerah lainnya. Penolakan ini pun berdampak pada rendahnya capaian cakupan Program vaksin MR tahap kedua yang ditargetkan mencapai 95 persen (Harsono, 2018).
Kementerian Kesehatan Republik Indonesia bahkan melaporkan bahwa hingga akhir Agustus 2018, cakupan program vaksin MR tahap kedua belum juga mencapai 50 persen dari target pemerintah (Astuti, 2018). Laporan ini pun kemudian menarik perhatian Media massa baik offline maupun online pun untuk memberitakan terkait kemungkinan tidak tercapainnya (gagalnya) target cakupan vaksin MR tahap kedua kepada khalayak. Sejumlah media massa bahkan dengan berani mengangkat isu kemungkinan gagalnya program tersebut saat program vaksin MR tahap kedua masih sedang berlangsung pada September 2018.

Republika Online dan Tempo.co adalah dua media berita online yang juga turut serta dalam memberitakan terkait kemungkinan gagalnya target cakupan Vaksin MR tahap kedua tersebut. Dalam pemberitaan kedua media ini kemungkinan gagalnya cakupan vaksin MR tahap kedua dikemas sesuai interpretasi dan sudut pandang masingmasing media. Sebagai akibatnya, ada isu terkait kegagalan tersebut yang ditonjolkan oleh Republika Online tetapi dilupakan/dihilangkan oleh Tempo.co. Sebaliknya, ada isu yang dihilangkan oleh Republika Online tetapi ditonjolkan oleh Tempo.co. 
Adanya perbedaan sudut pandang antara Republika Online dan Tempo.co dalam melihat peristiwa tersebut tidak terlepas dari realitas bahwa media bukanlah saluran yang bebas. Republika Online dan Tempo adalah dua media berita online besar di Indonesia yang setiap harinya memberitakan berbagai informasi kepada publik. Kedua media ini beroperasi dengan nilai-nilai dan pemihakannya yang berbeda-beda pula.

Republika Online adalah portal berita yang didirikan oleh Komunitas cendikiawan muslim sehingga nilai-nilai dan pandangan Islami sangat lekat dengan media ini. Hal ini tampak juga dalam konten-konten yang juga disajikan oleh Republika Online dalam portal beritanya. Namun demikian, Republika juga menyatakan dirinya sebagai media Muslim yang moderat dan menghargai perbedaan.

Berbeda dengan Republika Online, Tempo.co menyatakan diri sebagai media nasional yang netral dan terpercaya dengan taglinenya, "Enak dibaca dan bisa dipercaya". Sebagai media yang berada dibawah kelompok Tempo Media, ideologi dan pandangan media ini sama seperti Tempo cetak. Tempo.co mengklaim diri sebagai media yang selalu memberikan informasi sesuai nilai-nilai Jurnalisme dan meyakini bahwa jurnalisme tanpa nilai, tidak ada gunanya bagi kepentingan publik.

Berangkat dari perbedaan ideologi tersebut, peneliti kemudian tertarik untuk meneliti konstruksi realitas kegagalan cakupan program vaksin MR tahap dua dalam pemberitaan kedua media berita online tersebut. Mengingat jumlah pembaca media online juga semakin meningkat dari tahun ke tahun (Kurnia, 2018), peneliti berasumsi bahwa dampak pemberitaan kedua media ini, misalnya tentang fatwa haram vaksin MR oleh MUI, juga memiliki sumbangsih dalam memunculkan pro kontra hingga penolakan dari masyarakat.

Hal ini dapat diamati dari banyaknya kasus penolakan yang terjadi dalam dua tahap Imunisasi MR. Pada periode Imunisasi MR tahap pertama (2017), kasus penolakan hanya terjadi di beberapa sekolah di Yogyakarta. Namun pada Imunisasi MR tahap kedua (2018) jumlah kasus penolakan semakin meningkat dan terjadi di beberapa daerah seperti Aceh, Riau, Sumatera Barat, Kalimantan Selatan dan beberapa daerah lainnya.
Berangkat dari paparan latar belakang masalah di atas, penelitian ini kemudian difokuskan untuk menjawab pertanyaan: "Bagaimana konstruksi realitas kegagalan cakupan program vaksin measles rubella tahap kedua dalam pemberitaan Republika Online dan Tempo.co?"

\section{Literature Review}

\section{a. Konstruksi Realitas Media Massa}

Teori konstruksi realitas sosial pertama sekali diperkenalkan oleh Peter L. Berger dan Thomas Luckmann. Berger menyatakan bahwa realitas merupakan hasil dari kontruksi sosial. Realitas sosial dipahami secara objektif namun maknanya bersumber dari dan oleh hubungan subjektif setiap individu dengan dunia objektif (Ngangi, 2011:1-4).

Dalam pandangan konstruksi sosial, manusia dan masyarakat adalah produk yang dialektis, dinamis dan plural secara terus menerus. Hal ini berarti bahwa manusia adalah produk dari masyarakat, yang mana identitas, sikap, persepsi hingga perilakunya sangat dipengaruhi oleh lingkungan sosial di mana individu tersebut berada. Proses dialektis tersebut memiliki tiga tahapan yang oleh Berger disebut sebagai momen. Adapun tahapan tersebut adalah sebagai berikut (Bungin, 2009:204-205):

1. Eksternalisasi, yakni usaha manusia untuk mengekspresikan diri kedalam dunia tempat ia berada, baik dalam dunia mental maupun dalam dunia fisik

2. Objektivasi, yakni hasil yang dicapai baik mental maupun fisik dari kegiatan eksternalisasi manusia tersebut. Hasil eksternalisasi kebudayaan itu misalnya, manusia menciptakan alat untuk memudahkan hidupnya, kebudayaan non materil seperti bahasa dan lain sebagainya..

3. Internalisasi, merupakan proses penyerapan kembali dunia objektif ke dalam kesadaran sedemikian rupa sehingga subjektivitas individu dipengaruhi oleh struktur dunia sosial. Lalu berbagai unsur dari dunia yang terobjektifkan tersebut akan ditangkap oleh individu sebagai gejala realitas di luar kesadarannya. Melalui proses inilah manusia menjadi produk dari masyarakat 
Dalam pandangan Berger, realitas bukanlah sesuatu yang terbentuk secara ilmiah ataupun diturunkan oleh Tuhan melainkan dibentuk/dikontruksi sehingga realitas selalu berwajah ganda/plural. Setiap orang memiliki konstruksi yang berbeda atas realitas tergantung pengalaman, preferensi, pendidikan, dan lingkungan sosial di mana individu tersebut berada. Selain itu pengetahuan menurut Berger adalah merupakan hasil dari interaksi simbolik (knowledge is a product of symbolic interaction) di antara kelompok masyarakat tertentu (Eriyanto, 2015: 18).

Secara ontologis, realitas sosial yang dikonstruksi berlaku sesuai konteks yang dinilai relevan oleh pelaku sosial. Sedangkan secara epistemologis, realitas sosial dinilai sebagai produk interaksi antara peneliti dengan objek yang diteliti. Sementara dalam konteks aksiologi, peneliti dilihat sebagai fasilitator yang menjembatani keragaman subjektivitas pelaku sosial. Dengan demikian kajian konstruksi realitas sosial ditujukan untuk merekonstruksi realitas sosial secara dialektis antara peneliti dengan pelaku sosial yang diteliti (Eriyanto, 2015: 18-20).

Berdasarkan asumsi tersebut, maka berita sebagai produk media massa pun tidak lepas dari proses kontruksi para pembuatnya. Meskipun media berita mengklaim dirinya sebagai netral dan faktual namun dalam prosesnya media tetaplah bukan saluran yang lepas dari proses konstruksi.

Dalam memandang media, paradigma konstruktivis melihat media secara berbeda dengan pandangan kaum positivis. Menurut pandangan ini media bukanlah sekedar saluran yang netral tempat transaksi pesan terjadi. Sebab media juga adalah subjek yang mengkonstruksi realitas, lengkap dengan pandangan, bias dan pemihakannya. Oleh sebab itu media dilihat sebagai agen konstruksi yang aktif mendefinisikan realitas dan menyampaikannya kepada khalayak (Eriyanto, 2015: 26).

Dengan demikian berita yang kita baca setiap harinya bukan hanya menggambarkan realitas, melainkan juga menggambarkan konstruksi dari media itu sendiri. Lewat berbagai instrumen yang dimiliki oleh media, realitas tadi dibentuk dan disajikan kepada publik.

Dalam mengkonstruksi realitas di sekitar kita, media nyatanya memilih dan melakukan seleksi bagian mana yang diambil dan yang tidak diambil. Tidak hanya itu media juga berperan dalam mendefinisikan aktor yang terlibat dalam suatu peristiwa.

\section{b. Framing Media}

Framing pada mulanya dipahami sebagai struktur konseptul dan perangkat kepercayaan yang menyusun pandangan politik, kebijakan, wacana serta menyediakan kategori-kategori standar untuk mengapresiasi maupun menginterpretasi realitas tertentu. Lalu kemudian konsep ini dikembangkan oleh Goffman pada tahun 1974 yang melihat frame sebagai kepingan-kepingan perilaku yang membimbing individu dalam membaca realitas (Sobur, 2015:161-162).

Analisis ini telah banyak digunakan dalam literature kajian Ilmu Komunikasi untuk menggambarkan proses penyeleksian dan penyorotan aspek-aspek khusus sebuah realitas oleh media. Dalam perspektif Ilmu Komunikasi, framing digunakan untuk membedah cara-cara atau ideologi media saat mengkonstruksi fakta. Dengan kata lain framing adalah analisis yang mencoba mencermati strategi seleksi, penonjolan dan penautan fakta ke dalam berita yang lebih bermakna, lebih menarik, lebih berarti atau lebih diingat, untuk menggiring interpretasi khalayak sesuai prespektif penulisnya (Sobur, 2015162) .

Dengan kata lain framing adalah sebuah pendekatan untuk mengetahui sudut pandang wartawan dalam menyeleksi isu dan menulis berita tersebut. Cara pandang atau perspektif wartawan bagaimanapun akan menentukan fakta atau data mana yang akan diambil dan ditonjolkan dan yang mana yang akan dibuang. Dengan demikian, berita menjadi sangat manipulatif dan kebenarannya menjadi relatif (Eriyanto, 2015: 261).

Menurut Entman (Eriyanto, 2015: 221), framing dapat dilihat dalam dua dimensi besar yakni, seleksi Isu dan penekanan atau penonjolan aspek-aspek tertentu dari realitas isu. Penonjolan biasanya ditujukan untuk membuat informasi menjadi terlihat lebih bermakna, lebih menarik, dan berarti sehingga lebih diingat oleh khalayak pembaca. Realitas yang ditampilkan secara menonjol mempunyai kemungkinan lebih besar untuk diperhatikan oleh khalayak yang berdampak pada pemahaman khalayak terkait isu/realitas tersebut. 
Dalam prakteknya media memang melakukan seleksi atas isu/realitas yang terjadi di masyarakat. Entman (dalam Pawito, 2008:188) menyatakan bahwa:

"To frame is to select some aspect of a perceived reality and make them more salient in a communicating text, in such a ways as to promote a particular problem definition, causal interpretation, moral evaluation and treatment recomendation"

Yang berarti bahwa dalam membingkai berita, media memang melakukan seleksi dan menonjolkannya dalam teks berita sedemikian rupa untuk menggiring definisi tertentu tentang suatu persoalan, interpretasi, penilain moral atau pemberian saran. Ada beberapa strategi wacana yang umum digunakan oleh media seperti penempatan di bagian headline belakang atau depan, pengulangan, pemakaian grafis untuk mendukung dan memperkuat penonjolan, pemakaian label, asosiasi simbol budaya, generalisasi, simplikasi dan lainlainnya (Eriyanto, 2015:220).

Pemilihan/seleksi isu/realitas yang dilakukan media biasanya dipengaruhi oleh persfektif wartawan/editor. Namun demikian selain perspektif wartawan, nilai dan ideologi media juga sangat berpengaruh dalam pengambilan keputusan media terkait isu mana yang akan ditonjolkan dalam sebuah teks berita.

Menurut Entman (Eriyanto, 2015:224), frame berita timbul dalam dua level, yaitu: pertama, konsepsi mental yang digunakan untuk memproses informasi dan sebagai karakteristik dari teks berita. Kedua, perangkat spesifik dari narasi berita yang dipakai untuk membangun pengertian mengenai peristiwa. Frame berita dibentuk dari kata kunci, metafora, konsep, simbol, citra yang ada dalam narasi berita. Oleh sebab itu frame dapat diselidiki dari kata, citra, dan gambar tertentu yang memberikan makna tertentu dari teks berita. Kosa kata ditonjolkan dalam teks sehingga menonjol dibandingkan bagian lain dalam teks. Itu dilakukan lewat pengulangan, penempatan yang lebih menonjol dibandingkan bagian lain dalam teks.

Secara luas pendefinisian masalah ini menyertakan konsepsi dan skema interpretasi wartawan di dalamnya. Pesan, secara simbolik menyertakan sikap dan nilai. Ia membentuk dan menginterpretasikan makna yang terkandung di dalamnya. Konsep framing Entaman memang menggambarkan secara luas bagaimana peristiwa ditandakan oleh wartawan.

Abrar dalam Sobur (2015:173) menyebutkan bahwa pada umumnya terdapat 4 teknik mem-framing berita yang dipakai wartawan, yaitu: 1) Cognitive Dissonance (ketidaksesuaian sikap dan perilaku); 2) Empati (membentuk pribadi "khayal"), 3) Packing (daya tarik yang melahirkan ketidakberdayaan), dan 4) Assosociation (asosiasi, menggabungkan kondisi, kebijakan, dan objek yang sedang aktual dengan fokus berita). Sekurangnya ada tiga bagian berita yang bisa menjadi objek framing seorang wartawan, yakni: judul berita, fokus berita, dan penutup berita.

\section{d. Kontroversi Vaksin dalam Pemberitaan Media}

Adanya pro dan kontra terkait vaksin dan vaksinasi sebenarnya bukanlah isu yang baru lagi di masyarakat. Isu-isu tersebut sudah pernah terjadi sebelumnya, tidak hanya terjadi di Indonesia tetapi juga di berbagai belahan dunia lainnya. Sudah berulangkali pula isu miring vaksin menghiasi pemberitaan media massa baik cetak, elektronik maupun media online di berbagai negara, termasuk di Indonesia. Adapun isu umum yang diangkat adalah seperti kasus vaksin palsu, dampak vaksin (autisme, kecacatan hingga kematian) serta pro kontra halal tidaknya vaksin.

Di Amerika isu tentang dampak vaksin seperti munculnya autisme dan penyakit lainnya, menjadi isu utama pemberitaan media. Sedangkan di Indonesia isu vaksin yang beredar di masyarakat lebih banyak terkait pro kontra halal/haram vaksin. Meskipun sebelumnya masyarakat juga sempat dibuat resah dengan beredarnya vaksin palsu di sejumlah rumah sakit. Namun demikian isu pro kontra halal/haram kandungan vaksin nyatanya lebih mencemaskan khalayak ramai di Indonesia (Kemenkes RI, 2017).

Hal ini tampak pada proses pelaksanaan Program gratis vaksin MR yang dilaksanakan oleh pemerintah periode Agustus-September 2017 dan AgustusSeptember 2018 lalu. Program ini menggundang respon negatif berupa penolakan di sejumlah daerah baik di Pulau 
Jawa maupun di luar pulau Jawa. Media massa pun kemudian beramai-ramai memberitakannya kepada khalayak dengan berbagai sudut pandang.

Menurut Yuningsih (2017:10-11), dalam sebuah jurnal berjudul "Pro Kontra Imunisasi Campak-Rubella", alasan utama penolakan terhadap vaksinasi ini adalah karena belum adanya sertifikat halal untuk vaksin Campak-Rubella. Sampai saat ini, kehalalan vaksin Campak-rubella hanya didasarkan pada Fatwa MUI no. 04 tahun 2016 tentang imunisasi yang mana ditetapkan bahwa imunisasi itu mubah (bermanfaat) sehingga diperbolehkan.

Namun demikian, fatwa ini ternyata tidak serta merta mengubah respon sebagian masyarakat terhadap vaksin Campak-Rubella Measles. Pro dan kontra tidak lantas terselesaikan. Sejumlah pihak bahkan membenturkan persoalan ini dengan nilai-nilai ajaran agama yang mana vaksinasi dianggap sebagai suatu tindakan mendahului ketetapan Tuhan (Yuningsih, 2017: 11).

Pro kontra inilah yang kemudian dikemas media massa sebagai berita yang disajikan kepada masyarakat. Isu Vaksin MR yang belum mendapatkan sertifikat halal dari MUI dan isu Mubah vaksin MR menjadi topik utama yang diangkat dan diberitakan oleh media massa, khususnya media online. Adanya pemberitaan tersebut jelas-jelas membuat cemas masyarakat Indonesia yang sebagian besar adalah umat Islam. Masyarakat menilai bahwa pemerintah seharusnya menyediakan vaksin yang sudah halal dan mendapat sertifikat dari MUI.

Selain alasan tersebut, isu adanya Kejadian Ikutan pasca Imunisasi juga yang diberitakan oleh media massa menjadi salah satu alasan mengapa banyak orang tua menolak untuk mengizinkan anak-anaknya menerima vaksin MR.

\section{Metode}

Sudut pandang penelitian ini adalah sudut pandang kontruktivisme yang memandang bahwa pengetahuan adalah hasil konstuksi dan setiap manusia dianggap mengembangkan makna subjektif atas pengalaman-pengalaman mereka terkait benda-benda/objek maupun peristiwa yang ada di sekitar mereka (Ronda, 2018: 14). Sedangkan pendekatan yang digunakan adalah pendekatan kualitiatif dengan metode analisi isi kualitatif untuk membongkar konstruksi media online terkait kegagalan cakupan program vaksin tahap kedua di luar pulau Jawa.

Data dalam penelitian ini adalah beritaberita terkait kegagalan cakupan program vaksin MR tahap kedua di media berita online Republika.com dan Tempo.co periode September - November 2018. Berita ini berjumlah 15 berita yang terdiri dari 7 berita Tempo dan 8 berita Republika.

Untuk menganalisi data berita tersebut, peneliti menggunakan perangkat framing dari Robert Entman yang meliputi defining problem (pendefinisian masalah), diagnose causes (memperkirakan masalah atau sumber masalah), make moral judgement (membuat keputusan moral), dan treatment recommendation (menekankan penyelesaian) (Eriyanto, 2015: 221).

\section{Hasil \& Pembahasan \\ a.Frame Republika Online: Indeks
Rendahnya Kesadaran akan Kesehatan Media online Republika online} menerbitka laporan mengenai isu kegagalan cakupan program vaksin tahap kedua mulai 13 September- 1 November 2018 . Ada delapan (8) artikel berita yang ditulis oleh Republika online terkait isu tersebut. Masingmasing berita tersebut berjudul: "Tingkatkan Cakupan vaksin MR, Ini upaya Dinkes Aceh (Sulistyawati, 2018)", "Imunisasi MR Bebaskan Indonesia dari Belenggu Campak Rubella(Christyaningsih, 2018)", "Empat faktor Melencengnya capaian Imunisasi MR" (Rezkisari, 2018), "Imunisasi MR di Luar Jawa tak Capai Target (Sulistyawati, 2018”), "Sosialisasi vaksin MR diminta libatkan tokoh Agama (Sulistyawati, 2018"), "Pelaksanaan Imunisasi Diperpanjang (Sulistiwati,dkk., 2018)", dan "Imunisasi MR di NTT capai 76,17 \% (Amanda, 2018)". Berikut ini adalah bingkai Republika online dalam melihat kasus tersebut:

\section{Problem Identifification}

Republika online mengidentifikasi isu kegagalan cakupan vaksin MR tahap kedua sebagai persoalan kesehatan/ rendahnya kesadaran masyarakat akan kesehatan. Masyarakat dipandang belum menyadari manfaat penting dari vaksin MR. Selain itu masyarakat juga dinilai belum menyadari 
dampak yang ditimbulkan bila vaksinasi tidak dilakukan. Sudut pandang inilah yang kemudian mendorong Republika online untuk lebih banyak menyoroti upaya sosialisasi dan pendekatan kepada masyarakat dalam pemberitaannya.

Menarikanya dalam salah satu beritanya yang berjudul "Sosialisasi Vaksin MR diminta Libatkan Tokoh Agama" Republika Online menyebutkan bahwa keterlibatan tokoh agama akan sangat membantu proses sosialisasi vaksin MR. Namun demikian, Republika online samasekali tidak menyebutkan alasan pelibatan tokoh agama tersebut. Republika bahkan tidak membahas adanya fatwa haram vaksin MR oleh MUI yang menyebabkan pro kontra di masyarakat. Republika online terkesan menghindari penarikan persoalan tersebut ke ranah keyakinan maupun agama.

\section{Diagnose Caused}

Berdasarkan analisis terhadap delapan artikel berita yang diterbitkan oleh Republika online, ditemukan hanya satu judul berita yang mengangkat tentang penyebab kegagalan program tersebut. Hal ini menunjukkan bahwa Republika online cenderung berhati-hati dan mengindari pernyataan tegas terkait penyebab kegagalan program vaksin tersebut dalam pemberitaannya.

Dalam beritanya yang berjudul "Empat Faktor Penyebab Melencengnya Cakupan Vaksin", Republika online bahkan menyebutkan bahwa kegagalan program vaksin tahap kedua tidak disebabkan oleh satu faktor tertentu saja melainkan disebabkan oleh berbagai faktor. Faktor-faktor tersebut menurut Republika online meliputi faktor geografis daerah sasaran yang sulit, faktor ancaman terhadap para petugas kesehatan, faktor penerimaan masyarakat terhadap vaksin MR hingga faktor penerimaan masyarakat terhadap fatwa haram vaksin MR oleh MUI. Dalam penjelasan terkait faktorfaktor tersebut Republika juga berhati-hati untuk tidak mengklain salah satu faktor sebagai penyebab utama.

Selain menghindari pernyataan tegas terkait penyebab utama kegagalan program vaksin MR, Republika Online juga terkesan menghindari penyebutan fatwa haram vaksin MR oleh MUI sebagai penyebab utama kegagalan capaian program vaksin MR tahap kedua. Hal ini tampak pada penempatan faktor geografis di bagian awal berita yang kemudian diikuti oleh faktor ancaman petugas kesehatan dan diakhiri dengan faktor pro kontra halal/haram vaksin MR.

Menariknya, narasumber (Anung

Sugihantono, Dijen Pencegahan dan Pengendalian Penyakit) yang dikutip oleh Republika online dan Tempo.co dalam pemberitaan ini adalah sama, tetapi sudut pandang yang diambil dan ditonjolkan oleh kedua media ini jelas berbeda. Alih-alih menyebutkan faktor geografis dan faktor ancaman petugas kesehatan, Tempo.co justru hanya menyebutkan fatwa haram vaksin MR sebagai penyebab kegagalan tersebut.

\section{Make Moral Judgement}

Terkait kegagalan program vaksin MR tahap kedua, Republika online menilai bahwa sikap pihak-pihak yang menolak program vaksin MR tidaklah tepat dan tidak bijaksana karena dapat membahayakan kesehatan masyarakat. Republika dalam pemberitaannya juga menyebutkan bahwa sikap menolak dan tindakan provokasi untuk menolak vaksin MR adalah tindakan tidak adil dan tidak proporsional karena dapat mengakibatkan keresahan dan kegaduhan di masyarakat.

Namun demikian, Republika tidak secara tegas menyebutkan siapa pihak-pihak tersebut. Republika online terkesan menghindari penyebutan pihak manapun sebagai pihak yang dianggap tidak bijak maupun adil tersebut. Ini menunjukkan bahwa Republika ingin menujukan pernyataan ini kepada semua pihak tanpa terkecuali.

Selain menilai bahwa pihak-pihak yang menolak vaksin MR adalah tidak adil dan tidak bijaksana, Republika online dalam pemberitaannya juga mendukung tindakan/upaya pemerintah yang memperpanjang periode Imunisasi MR karena dinilai dapat meningkatkan cakupan program vaksin MR dan bermanfaat bagi masyarakat. Hal ini tampak dari sejumlah artikel berita yang diangkat oleh Republika online yang menyebutkan tentang upaya-upaya pemerintah untuk meningkatkan cakupan vaksin di daerah luar pulau Jawa.

\section{Tretment Recommendation}

Untuk meningkatkan capaian cakupan program vaksin MR, Republika online menyarankan agar pemerintah tetap melanjutkan upaya sosialisasi dan memperpanjang periode pelaksanaan program imunisasi MR. Tidak hanya itu, Republika online juga menghimbau agar masyarakat agar 
tidak ragu untuk turut serta bekerjasama dalam meningkatkan cakupan vaksin demi kebaikan bersama.

Republika online juga menyarankan agar pemerintah daerah di luar pulau Jawa (khususnya daerah-daerah yang cakupan vaksin MR nya rendah) bekerjasama dengan para pemuka agama. Selain itu pemerintah juga diharapkan menggunakan berbagai media dalam proses sosialisai vaksin MR agar komunikasi menjadi efektif.

\section{b.Frame Tempo.co: Ancaman Ketahanan Nasional dan Persoalan Agama}

Tempo.co menerbitkan 7 berita terkait kegagalan program vaksin MR tahap kedua pada periode September-November 2018. Ketujuh berita ini berjudul, "Imunisasi Rendah,32 Juta Anak Terancam Virus Campak Rubellla (Widiastuti, 2018)", "Menkes Nila Moeloek: Aceh Daerah Terendah Capaian Vaksin MR (Hantoro, 2018)', Vaksin MR dan Ancaman Penyakit Bak Kutukan (Hantoro, 2018)", "MUI Haramkan Vaksin MR, Ini Kata Ilmuan dari Berbagai Perspektif (Prima, 2018)", "Kementerian Kesehatan Kesulitan Melakukan Vaksin MR di Luar Jawa (Amirullah, 2018)", "Begini Efeknya Jika banyak yang Tidak Imuniasasi Vaksin (Widiastuti, 2018)", "Penolakan Imunisasi, Petugas Diusir Hingga diacam Parang (Hantoro, 2018)". Berikut ini merupakan analisis frame Tempo.co dalam memberitakan isu tersebut:

\section{Problem Identification}

Berdasarkan hasil analisis terhadap 7 artikel berita di Tempo.co, ditemukan bahwa Tempo.co lebih cenderung memaknai kegagalan Program vaksin MR sebagai sebuah persoalan Acaman bagi ketahanan Nasional. Hal ini tampak jelas tidak saja dalam teks/isi berita yang disampaikan tetapi juga dalam beberapa judul berita Tempo.co yang menggunakan kata "ancaman" maupun kata bermakna serupa di dalamnya seperti, "Imunisasi Rendah, 32 Juta Anak terancam Virus Rubella", "Vaksin MR dan Ancaman Bak Kutukan", Generasi di Gerus Virus”, dan Begini efeknya Jika Banyak yang Tidak Imunisasi Vaksin MR"

Pendefinisian masalah kegagalan Program Vaksin MR sebagai "acaman" jelas menunjukkan bahwa Tempo.co menggangap bahwa vaksinasi adalah hal yang sangat penting dan dapat membahayakan negara bila tidak dilakukan. Bahkan dalam salah satu artikel beritanya, Tempo.co menganalogikan tubuh kita sebagai negara yang memiliki banyak tentara. Meskipun dalam kondisi sehat/aman, para tentara tetap harus dilatih agar suatu waktu ada ancaman, kondisi pertahanan negara tetap kuat menghadapi musuh. Dalam hal ini imunisasi dinilai akan menguatkan negara agar terbebas dari ancaman (penyakit) di masa depan.

Dalam bingkai Tempo.co, ancaman penyakit akibat kegagalan cakupan program vaksin MR cukup serius sehingga Tempo.co menyebutnya "bak Kutukan". Hal ini berarti bahwa dalam ancaman penyakit akan pasti tidak bisa dihindari (kutukan) bila imunisasi gagal dilakukan. Untuk itu Tempo.co lewat pemberitaannya mencoba membangun kesadaran pembaca untuk melihat realitas kegagalan capaian Program vaksin MR sebagai realitas yang bisa mengancam generasi penerus bangsa.

\section{Diagnose Caused}

Dalam sudut pandang Tempo.co peristiwa kegagalan Program vaksin MR tahap kedua (luar pulau Jawa) disebabkan oleh adanya fatwa haram vaksin MR yang dikeluarkan oleh MUI. Tempo.co memaknai bahwa pro kontra dan penolakan yang muncul di masyarakat berakar dari adanya fatwa tersebut. Bahkan dalam salah satu beritanya yang berjudul "Vaksin MR dan Ancaman Bak Kutukan", Tempo dengan tegas menyebutkan bahwa kegagalan capaian program vaksin MR tahap kedua adalah akibat fatwa haram.

Berbeda dengan Republika yang dalam pemberitaannya menyebutkan beragam faktor yang menyebabkan kegagalan program vaksin MR tahap kedua, Tempo hanya menyebutkan bahwa Fatwa haram MUI-lah sebagai penyebabnya. Padahal, sumber yang dikutip oleh kedua Tempo.co sama sekali tidak menyebutkan faktor lain yang mungkin menyebabkan kegagalan program vaksin MR.

Hal ini, secara tidak langsung menunjukkan bahwa menurut pandangan Tempo.co, MUI-lah yang harusnya bertanggungjawab atas munculnya pro kontra dan terjadinya kegagalan program vaksin MR di masyarakat luar Pulau Jawa.

\section{Make Moral Judgement}

Berdarsarkan analisis 7 artikel berita di Tempo.co terkait kegagalan Program Vaksin MR kedua, peneliti menemukan bahwa Tempo.co juga melakukan moral judgement terhadap pihak-pihak yang dilibatkan dalam 
pemberitaannya. Tempo.co menilai bahwa sikap pemerintah Aceh yang meminta penundaan program vaksin MR sangatlah tidak tepat karena berpotensi untuk meningkatkan tingginya persebaran virus MR di Aceh. Tempo.co menilai bahwa pemerintah seharusnya bertanggungjawab untuk untuk meningkatkan taraf kesehatan masyarakat.

Selain itu Tempo.co juga menilai bahwa tindakan masyarakat di berbagai daerah (Gorontalo, Kalimantan Selatan, Sumatera Barat) yang mengancam menyerang petugas kesehatan sebagai tindakan yang tidak baik karena dapat mengancam keselamatan 32 juta anak Indonesia.

Tempo.co juga memberikan apresiasi bagi pemerintah tokoh agama yakni Ma'aruf Amin dan Ustad Somat yang turut serta menghimbau agar masyarakat turut serta mendukung vaksinasi MR di daerah.

\section{Tretment Recommendation}

Untuk menyelesaikan persoalan kegagalan capaian program vaksin MR (tahap kedua), Tempo.co mendorong para tokoh agama untuk terlibat dalam menyukseskan program vaksin MR. Tempo bahkan mendukung upaya MUI untuk turun tangan langsung dalam proses sosialisasi di lapangan.

Tempo.co beranggapan bahwa dukungan dari tokoh agama dan pelibatan tokoh agama dalam sosialisasi akan mengubah pandangan masyarakat muslim terkait vaksin MR yang diisukan mengandung zat yang tidak halal. Hal ini didasarkan pada pandangan Tempo.co yang menilai bahwa penyebab utama kegagalan program vaksin adalah fatwa haram MUI.

Selain itu Tempo.co juga mendukung pemerintah untuk memperpanjang periode imuniasasi MR sama seperti yang disarankan oleh Republika.com.

\section{Pembahasan}

Teori konstruksi realitas sosial menyatakan bahwa media adalah agen yang mengkonstruksi realitas berdasarkan pandangan, nilai, bias dan keberpihakannya. Hal ini berarti bahwa berita yang diproduksi oleh media adalah hasil interpretasi media atas peristiwa ataupun fakta-fakta yang terjadi di sekitar kita.

Pada tahap awal produksi berita, interpretasi wartawanlah yang menentukan batasan-batasan apa yang dianggap berita dan mana yang tidak berita. Tahapan ini kemudian dilanjutkan di meja redaksi dimana beritaberita tersebut disortir kembali sebelum sampai ke tangan pembaca. Hal ini menunjukkan bahwa interpretasi wartawan dan interpretasi editorlah yang kemudian menjadi penentu bagaimana sebuah berita dibangun dan disampaikan kepada publik.

Menurut Daniel Hallin, media menempatkan berita dalam 3 bidang peta ideologi yakni Sphere of Deviance (Penyimpangan), Sphere of Legitimate Controversy (kontroversi) dan Sphere of Consensus (konsensus) (Eriyanto, 2015: 150152). Berdasarkan peta tersebut, peneliti menemukan bahwa peristiwa kegagalan imunisasi MR baik di Tempo.co dan Republika online menggunakan peta ideologi menyimpang (deviance) yang berarti peristiwa tersebut dianggap buruk.

Namun demikian Tempo.co dan Republika online memiliki sudut pandang (alasan) yang berbeda mengapa peristiwa tersebut dianggap buruk. Bagi Tempo.co, kegagalan Imunisasi Vaksin MR tahap kedua buruk karena berpotensi besar mengancam ketahanan nasional. Tempo.co bahkan menggambarkannya sebagai "kutukan" bagi generasi bangsa. Sementara Republika online menganggap hal tersebut buruk karena dapat menimbukan gangguan kesehatan pada janin (kecacatan dan kematian). Republika online menilai bahwa adanya penolakan terhadap vaksin MR adalah indikasi bahwa kesadaran masyarakat akan kesehatan masih rendah. Namun demikian, Republika tidak menyatakan bahwa peristiwa kegagalan ini adalah sebuah ancaman sebagaimana yang dikonstruksi oleh Tempo.co.

Adanya perbedaan sudut pandang ini pun berdampak pada munculnya perbedaan penyelesaian yang diusulkan oleh kedua media online ini. Republika online lebih banyak menggunakan frame upaya peningkatan kesadaran akan pentingnya imunisasi dalam pemberitaannya karena dalam sudut pandang Republika online peristiwa tersebut terjadi karena rendahnya kesadaran masyarakat akan kesehatan. Republika online juga terkesan berhati-hati atau bahkan menghindari pembicaraan terkait isu agama (fatwa haram MUI) dalam pemberitan peristiwa tersebut karena menyangkut Islam.

Berbeda dengan Republika online, Tempo.co sebaliknya dengan berani 
menyatakan bahwa pelibatan tokoh agama Islam dan MUI adalah salah satu cara untuk menyelesaikan persoalan tersebut. Tempo.co menganggap bahwa MUI dan tokoh agama Islam harus bertanggungjawab atas munculnya berbagai penolakan imunisasi di daerah-daerah seperti Riau, Aceh, Kalimantan Selatan dan yang lainnya. Hal ini karena Tempo.co menilai bahwa kegagalan cakupan vaksin di daerah luar Pulau Jawa disebabkan oleh Fatwa Haram vaksin MR dari MUI. Tempo.co dengan tegas menyatakan bahwa fatwa MUI-lah yang memunculkan pro kontra hingga memunculkan penolakan di masyarakat yang mayoritas penduduknya beragama Islam seperti di Sumatera Barat, Riau dan Aceh..

Berdasarkan realitas tersebut dapat dilihat bagaimana peta ideologi dan nilai yang dianut oleh kedua media online ini

\section{Referensi}

Amanda, G. (2018). Imunisasi MR di NTT Capai 76,17 \%. Republika.co.id. Diakses April 2019.

Amirullah. (2018). Kementerian Kesehatan Kesulitan Melakukan Vaksin MR di Luar Jawa. www.tempo.co. Diakses April 2019

Astuti, I. (2018). Cakupan Sementara Imunisasi MR di 28 Provinsi 41,14\%.www.mediaindonesia.com. Diakses pada Maret 2019

Bungin, B. 2009.Sosiologi Komunikasi: Teori Paradigma, dan Diskursus Teknologi Komunikasi di Masyarakat. Jakarta:Kencana Prenada Media Group

Christiyaningsih dan Rezkisari, I. (2018). Imunisasi MR Bebaskan Indonesia dari Belenggu Campak Rubella. Republika.co.id, Diakses April 2018

Juniman.2018.Prokontra-masyarakatmenyoal-halal-haram-vaksin-mr. www.cnnindonesia.com.Diakses November 2018

Karman. 2015. Konstruksi Realitas Sosial sebagai Gerakan Pemikiran. Jurnal Balai Pengkajian dan Pengembangan Komunikasi dan Informatika (BPPKI), Volum 5 No 3 Maret 2015 ISSN: 2087-0123. mempengaruhi sudut pandang yang diambil dalam membingkai (membangun) kasus tersebut dalam pemberitaan mereka.

\section{Kesimpulan}

Berdasarkan analisis dan pembahasan yang telah dilakukan, dapat disimpulkan bahwa kedua media baik Republika online maupun Tempo.co memiliki bingkai yang berbeda dalam memaknai kasus kegagalan program vaksin MR tahap kedua yang dilaksanakan oleh pemerintah. Perbedaan ini berkenaan dengan nilai dan ideologi kedua media. Tempo.co dalam pemberitaannya cenderung melihat kepentingan negara sedangkan Republika online cenderung menghindari perdebatan terkait pro kontra haram/halal vaksin dalam pandangan Islam.

Cresswell, J.W. (2012) Research Design: Pendekatan Kualitatif, kuantitatif dan mixed. Yogyakarta: Pustaka Pelajar

Eriyanto. 2015. Analisis Framing: Konstruksi, Ideologi dan Politik. Yogyakarta: LKiS

Hantoro, J. (2018). Penolakan Imunisasi, Petugas Diusir Hingga diancam Parang. www.tempo.co. Diakses April 2019.

(2018). Vaksin MR dan Ancaman Penyakit Bak Kutukan. www.tempo.co. Diakses April 2019

Harsono, F.H. (2018). Delapan (8) Provinsi di Luar Jawa dengan Cakupan Imunisasi MR Fase 2 Terendah. www.liputan6.com.Diakses pada Maret 2019

Juniman, P.T. (2018). Prokontra Masyarakat Menyoal Halal Haram Vaksin MR.www.cnnindonesia.com .Diakses 18 Februari 2019. Kementerian Kesehatan Republik Indoneisa. 2017. Petunjuk Teknis Kampanye Imunisasi Rubella Measles. Jakarta: Direktorat Jenderal Pencegahan dan Pengendalian Penyakit Kementerian Kesehatan

Kurnia, D. dan Assidiq, Y. (2018). Jumlah Pembaca Media Berita Daring 
Terus Meningkat. Republika.co.id. Diakses April 2019.

Martono, N. (2015. Metode Penelitian Sosial: Konsep-konsep Kunci. Jakarta:Rajawali Press.

Ngangi, C.R. 2011.Konstruksi Sosial dalam Realitas Sosial. ASE - Volume 7 Nomor 2, Mei 2011: 1 - 4

Pawito. 2008. Penelitian Komunikasi Kualitatif. Yogyakarta: LKiS

Prima, E. (2018). Begini Efeknya Jika Banyak yang Tidak Imunisasi

Ronda, A.M. 2018. Tafsir Kontemporer Ilmu Komunikasi. Tangerang: Indigo Media

Rosdakarya

Sobur, A. 2015. Analisis Teks Media: Suatu Pengantar Untuk Analisis Wacana, Analisis Semiotik, dan analisis Framing. Bandung: Remaja

Sulistiwati, L., dkk. (2018). Pelaksanaan Imunisasi Diperpanjang. Republika.co.id. Diakses pada April 2019.

(2018). Sosialisasi Imunisasi MR diminta Libatkan Tokoh Agama. Republica.co.id. Diakses April 2019.
Vaksin. www.tempo.co. Diakses April 201 (2018). MUI Haramkan

Vaksin MR, Ini Kata Ilmuwan dari Berbagai Perspektif. www.tempo.co. Diakses April 2019

Rezkisari, I. (2018). Empat Faktor Melencengnya Capaian ImunisasiMR. Republika.co.id. Diakses pada April2019.

Sulistyawati, L.(2018).Tingkatkan Cakupan Imunisasi MR, Ini Upaya Dinkes Aceh. Republika.co.id. Diakses April 2019

Tarigan, M. (2018). Kontroversi Vaksin $M R$, Kenali Manfaat Vaksin dan Bahaya Virusnya.www.tempo.co. Diakses April 2019

Widiastuti, R. (2018). Imunisasi Rendah, 32 Juta Anak Terancam Virus Campak Rubella. www.tempo.co. Diakses April 2019

Yuningsih, R. 2017.Pro-Kontra Imunisasi Campak Rubella. Majalah Info Kesejahteraan Sosial, Vol. IX, No. 16/II/Puslit/Agustus 